\title{
SUMMARY OF THE 1978 NORTHWESTERN WYOMING ARCHAEOLOGICAL PROJECT
}

\author{
Gary A. Wright \\ Department of Anthropology \\ State University of New York \\ Albany
}

Only a brief summary of the results can be presented at this time as the data are still being analyzed.

Mitigation was completed on the reconstruction of the Mammoth Water System, Yellowstone National Park. The system begins at the intake at the confluence of Indian Creek and the Gardner River. The pipeline runs into Mammoth Hot Springs. Our field research consisted of the recording of cultural resources, test excavations at 50 meter intervals along the pipeline, and the excavation of the Bear Claw site (48YE504). The latter produced a range of projectile point types suggesting intermittent occupations of the site back to at least 7000 B.P. Also recovered were parts of a butchered elk (Cervus canadensis) in association with obsidian tools. Eventually, we will be able to obtain obsidian hydration dates from the se tools and hence some minimal data concerning the temporal duration of elk in northern Yellowstone Park.

Stuart Reeve continued his investigations of the plant geography and ethnobotany of northwestern Wyoming. During 1978 he concentrated on blue camas (Camassia quamash) meadows, their community associations, and the correlation of archaeological sites with this hypothesized major prehistoric resource base. Several new sites were recorded by Reeve along the Falls River in extreme southwestern Yellowstone Park. These sites are located adjacent to blue camas meadows, and they appear to provide a seasonal prehistoric occupation link between winter camps to the west of the Teton Range and the large late spring-early summer site at the northern end of predam Jackson Lake (= the Lawrence site, 48TE509). Mr. Reeve also began a production study of a blue camas meadow near the Lawrence site.

My own work was limited to cultural resource inventories of 28 proposed construction projects in Grand Teton and Yellowstone National Parks.

Reports and recommendations have been submitted to the National Park Service, Midwest Archaeological Center, Lincoln, NB.

In addition, reports have now been completed on several major aspects of our field research. These include evaluations on the Sheepeater Bridge site (48YE320) in Yellowstone Park and the Lawrence site in Grand Teton Park (Reeve, et al., 1978; Reeve, Wright and Mecham, 1978), and an analysis of northwestern Wyoming in regards to the ethnic identification of the prewhite inhabitants of the area (Wright, 1978). 


\section{Literature Cited}

Reeve, S. A., T. Marceau and G. A. Wright. 1978. Mitigation of the Sheepeater Bridge site (48YE320), Yellowstone National Park. Manuscript on file, Midwest Archaeological Center, Lincoln, NB.

Reeve, S. A., G. A. Wright and P. Mecham. 1978. Archaeological investigations of the Lawrence Site (48TE509), Grand Teton National Park. Manuscript on file, Midwest Archaeological Center, Lincoln, NB.

Wright, G. A. 1978. The Shoshonean Migration Problem. Plains Anthropologist, $23: 113-137$. 